\title{
Utilization of Displaced Land of Former Red Stone Excavation for Milkfish Farming by Stick Net Cage System (A Case Study at Gentungan, Gowa Regency, South Sulawesi, Indonesia)
}

\author{
Abdul Haris Sambu ${ }^{1}$ \\ ${ }^{1}$ Aquaculture Department, Agriculture Faculty, University of Muhammadiyah Makassar \\ Correspondence: Abdul Haris Sambu, Aquaculture Department, Agriculture Faculty, University of \\ Muhammadiyah Makassar. E-mail: ah.sambu@unismuh.co.id
}

Received: March 24, 2017

Accepted: April 25, 2017

Online Published: June 14, 2017

doi:10.5539/mas.v11n7p68

URL: https://doi.org/10.5539/mas.v11n7p68

\begin{abstract}
This study was conducted at Gentungan village, West Bajeng District, Gowa Regency, South Sulawesi Province, Indonesia for four months, i.e., from March to July 2016. The study aimed to (1) determine the feasibility of water quality for nursing at the former land of red stone excavation, (2) analyze the growth rate, and (3) analyze the survival rate. Method used in this study was the stick net cage system which sized $4.0 \times 3.0 \times 1.5 \mathrm{~m}$, with an average density was $20 \mathrm{fish} / \mathrm{m}^{3}$. The results showed that (1) the measurement and analysis results of water quality during the nursering period were still in the limits of feasibility as presented in Table 1, (2) the analysis results of growth rate were obtained an average growth rate of 117 gram for 160 days, and (3) the survival rate was $86 \%$.
\end{abstract}

Keywords: Fish farming, displaced land, stick net cage system

\section{Introduction}

\subsection{Background}

In the line with the rapid development in various fields, including infrastructure developments such as offices, trades, housing, tourisms, road and bridge constructions which need the natural resources of minerals such as natural stone, sand and red stone for each year have increased. Consequently, the use of natural resources has give rise to new problems, such as the exploitation of mineral resources on a large scale and constantly done by ignoring the principles of sustainable environment management. One of the problems arising from the utilization of mineral resources is deforestation and damage to watersheds (South Sulawesi's BPS, 2013).

Gowa regency as a buffer zone or the hinter land of Makassar city becomes the main target for the natural resources supply to stimulate the infrastructure development of Makassar city and its surroundings. The need of natural stone, sand, and soil embankment is generally obtained along the Jeneberang watershed which is one of the largest watersheds in the southern part of South Sulawesi as the main source of water supply in daily life for Makassar city and its surroundings. The existence of Jeneberang river is very important in responding to the various needs of the inventory as a source of drinking water, sources of irrigation agriculture and livestock (Gowa's BPS, 2013).

On the other hand, the requirements of red stone are generally obtained in three districts in Gowa regency, namely Pallagga, Bajeng and Bontonompo district which become the industrial center of the red stone. From the former excavation of red stone industry, it has caused damage to the environment, namely the abandoned or displaced land. The land of former red stone and sand excavation has lost its status of the gardens or rice fields into a puddle of water which generally overgrown with grass, therefore, it becomes the center of the proliferation of various reptiles, such as mosquitoes, mice, lizards, snakes, and other animals. The Gentungan village in West Bajeng district is one of the industrial center villages of the red stone from its total territory of $9,06 \mathrm{~km}^{2}$ or 906,47 ha, which is distributed in the six hamlets, about 35 ha or $3.9 \%$ become displaced lands, in addition to, there are also natural marshes which are approximately of 75 ha or $8.3 \%$. Both of these land types have lost their ecological, economic, and social function and their status are abandoned land (Gentungan's BPD, 2014).

One of the portraits for abandoned land of the former industrial red stone excavation at Borisalama of Gentungan 
village seems only overgrown by the weeds as presented in Figure 3. The next portrait of abandoned land in the form of swamp in Romanglompoa, Gentungan village, also looks overgrown with grass as presented in Figure 4. If there is no attempt to utilize both of these lands, they will lose their large functionality economy. If these lands are converted to rice plants, they can produce average of rice as many as $3,500 \mathrm{~kg} \mathrm{ha}^{-1}$ or equivalent with IDR $17,500,000 \mathrm{ha}^{-1} / \mathrm{th}^{-1}$, it means that Gentungan village suffers the economic losses amounting to IDR 1.9 billion per year (Gentungan's BPD, 2014).

One of the efforts to optimize the industrial red stone excavation land and abandoned swampland is business activities for various kinds of fish farming. But the action plan of this activity will focus on milkfish farming, with the consideration that the milkfish type has several advantages either ecologically or economically and socio-cultural community. The milkfish or Oreochromis niloticus has several advantages when compared with the other types of freshwater fish, namely (1) tolerance on the environment, (2) fast growth rate, (3) reproduce naturally, and (4) the market opportunity is relatively high because of the much-loved by community both of households needs and stall needs (Suyanto, 2002, and Sudirman \& Irwan, 2003).

The milkfish farming methods, which are applied on the land of former industrial red stone excavation and swampland, is by using two methods, namely (1) the large-scale that is sowing the seeds freely to the entire expanse of puddles, and (2) the small-scale system by using floating net cage (KJA) or stick net cage (KJT). Both of these methods aim to compare and evaluate the advantages and disadvantages of the ecological and economic aspects in order to realize the optimal and sustainable of fish farming (Poernomo, 1992). This concept should be the foundation for utilization of natural resources which economically meet the needs of current generations and try to preserve it in order to fulfill the needs of future generations (Dahuri et al., 1996).

\subsection{Study Objectives}

The objectives of this study were (1) to determine the feasibility of water quality during the nursing period at the former land of red stone excavation, (2) to analyze the growth rate, and (3) to analyze the survival rate of the milkfish farmed.

\subsection{Significance of Study}

The significances of the activities in this study are expected to (1) improve the public knowledge about the methods of milkfish faming at the former land of red stone excavation, (2) optimize the former land of industrial red stone excavation and swampland, (3) to fulfill the nutrition of the farmers' family and society, so that the productivity of the Gentungan village increased and have certain quality, (4) to increase the society income and welfare, and (5) to improve the education and health of Gentungan society so it improves the human development index (HDI).

\section{Methodology}

\subsection{Location and Time}

This study was conducted in Borissalama, West Bajeng district. The study was conducting during the period of four months, i.e., from March to August 2016. The location of this study is presented in Figure 1.

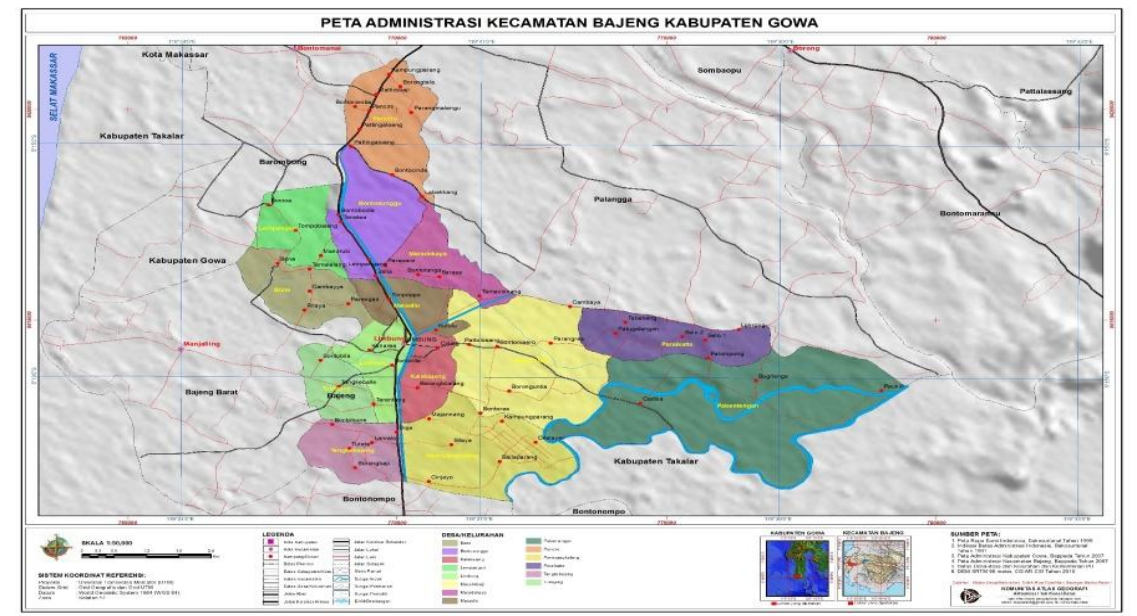

Figure 1. The Research's Location in Gentungan village, West Bajeng district, Gowa regency, South Sulawesi province, Indonesia 


\subsection{Instruments}

The tools used in this study included (1) thermometer, (2) pH meter, (3) the water level scale board, (4) scale, (5) bottles for water samples, (6) chopping knife, (7) hammer, (8) saw, and (9) meter roller. While the materials used in this study consisted of (1) seed milkfish as many as 250 fish with an weight average of 5 grams, (2) fish feed, i.e., pellets as many as 21.25 kilogram, (3) 10 rods of bamboo to the frame and pole cages, (4) nails, (5) straps, and (6) nylon net of 35 meters for a cage unit sized $4 \times 3 \times 1.5$ meter.

\subsection{The Procedure of the Study}

The procedure of this study was divided into three stages, namely: (1) administration stage, (2) implementation stage, and (3) reporting stage. The administration stage included site selection and research topic, proposal generation, signing of the cooperation between the implementing partners of the researcher and farmer's groups, the ratification proposal by the dean and the chairman of the institute for the development of research and community service, and proposal submission to the Ministry of Research and Higher Education. The implementation stage was conducted after passing the selection and receiving budget allocation, research site preparation, tools and materials preparation, designing stick net cages, and nursing process.

The milkfish seeds were spread on the stick net cages with density capacity of $20 \mathrm{fish} / \mathrm{m}^{3}$. Feeding was done twice a day, i.e., morning and afternoon with food convention ration of $1: 2$, which meant that the provision of one kilogram of feed would produce 2 kilogram of milkfish. The water quality measurement was conducted for eight times during a four-moths nursing, it meant that the quality measurements were conducted once in two weeks. The water management system was only the addition and no expenses. The addition of the water volume was conducted once in a week in order to maintain the pond water level as high as 1.25 meters.

The addition of the water volume was conducted by the gravitational system that opened the L pipe-shaped by rotating or revoking that L-pipe. The added duration of water volume was conditioned with the water level as desired. The water security system was conducted in order to (1) prevent the large-sized rubbish by installing bila-bila or hedge which made from bamboo and it was put outside the door, (2) prevent the entry of mud particles or suspended along the water on nursing pool, at the end of the pipe that serves as a door mounted put the green small filter.

\subsection{The Design of the Study}

This study was conducted in an area of red stone excavation sized of 0.25 ha which was the square size. The cage types, which was used as the fish farming place on this formerly land, was the stick net cage which sized 4 $\times 3 \times 1.5$ meters. The stick net cage was put on one of the pool corners, i.e., the adjacent corner of the floodgates which was aimed for the organisms farming always got fresh water directly comes from the channel. The layout setting of stick net cage was presented in Figure 2.

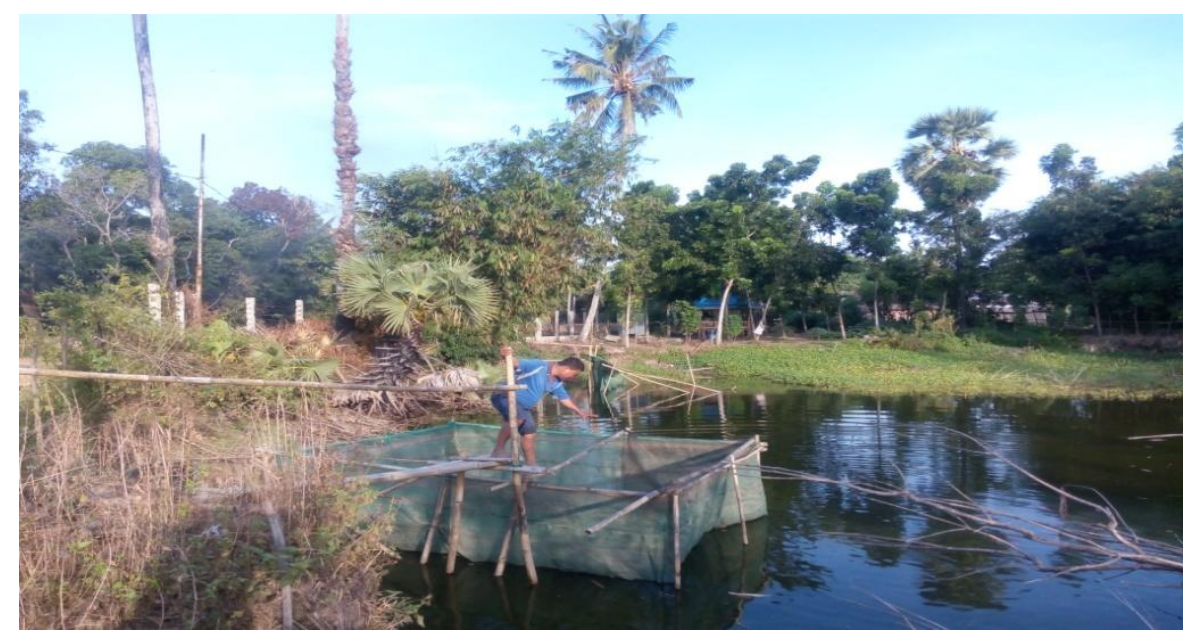

Figure 2. The Design of Stick Net Cage Method for Fish Farming in the Land of Former Red Stone Excavation

\subsection{Data Analysis}

The data analysis used consisted of (1) descriptive qualitative analysis was used to analyze the feasibility of 
water quality, i.e., compared the measurement results of farming water quality with the technical requirement standard of fish farming, and (2) quantitative analysis was used to analyze the growth and survival rate.

\section{Results}

\subsection{The General Description of the Location}

Administratively, Gentungan village is one of the villages in West Bajeng district, Gowa regency, South Sulawesi, Indonesia. While, geographically, Gentungan is in the north of Borimatangkasa and Tanabangka villages, in the east of Bulogading village of Bontonompo district, in the south side of Romanglasa village of Bontonompo district, and in the west side by Bontomanai village.

Gentungan village is one of the center villages of red stone industry in West Bajeng, Gowa regency, which has total territory area of $906 \mathrm{~km}^{2}$ or 906,47 ha distributed in six hamlets, hence, about 36 ha or $3.9 \%$ has land abandoned due to the use of red stone quarry. Besides, there are also natural swampland area of 75 ha or $8.3 \%$ (Gentungan's BPD, 2015). Both types of these lands become the abandoned land and overgrown wit weeds and some kinds of reptiles. However, in rain season, the variety of fish farming can be conducted if these lands are utilized optimally and they can also be planted several kinds of vegetables in dry season (Ciptanto, 2015).

\subsection{The Results of Water Quality Measurement}

The water quality is one of the critical success factors in pond fish farming. The measurement results for four months and eight measurements were obtained that the average of water quality as presented in Table 1.

Table 1: The Results of Water Quality Measurement and Analysis for Four Months (March to June 2016)

\begin{tabular}{lccccc}
\hline \multirow{2}{*}{ Parameter } & \multicolumn{2}{l}{ Months } & & \multicolumn{2}{c}{ Method } \\
\cline { 2 - 5 } & March & April & Mai & June & \\
\hline Temperature (c $\left.{ }^{0}\right)$ & 28.5 & 28.7 & 29.5 & 30.1 & insitu \\
Water pH & 7.50 & 7.30 & 7.20 & 6.70 & insitu \\
Clarity (m) & 27.5 & 29.5 & 32.3 & 35.1 & insitu \\
Depth (m) & 1.75 & 1.61 & 1.55 & 1.40 & insitu \\
Oxygen (ppm) & 5.70 & 5.50 & 4.20 & 4.10 & a.lab \\
Ammonia (ppm) & 0.02 & 0.03 & 0.03 & 0.04 & a.llab \\
Sulfide Hydrogen & 0.05 & 0.05 & 0.06 & 0.07 & a.lab \\
(ppm) & & & & & \\
\hline
\end{tabular}

Source: The Research Results (2016)

Based on the measurement and water quality sampling in this study, there were three things that needed to be established, namely (1) the station provision, (2) the time provision, and (3) method provision. The third provisions were conducted to get the results of water quality measurements that representative and had high validity and reliability.

First, the determination of measurement and sample collection stations set at three corners of pool, namely (1) the corner, (2) the middle, and (3) in the stick net cage of the fish farming.

The second, the determination of measurements time and taking water sampling was conducted eight times, i.e., they were conducted twice for each month in order to obtain the average of water quality monthly. Taking water sample and measurements were conducted to know the changes or fluctuations in water quality parameters for four months of nursing process. It is important to know that whether the weather factors affected the quality parameters significantly, as the basis for establishing the optimal time in the next farming process.

The third, the water measurement method and taking water sample were conducted in two ways, namely to (1) the water temperature, water $\mathrm{pH}$, water clarity, and depth of water pool which were conducted by insitu, i.e., the direct measurement on observation site, and (2) oxygen, ammonia, and sulfide hydrogen which were conducted by using laboratory analysis. The measurement results of insitu and laboratory analysis showed that the water quality parameters, which were observed during nursing process occurred monthly fluctuations, but they were not significant because each parameter was in the optimal range to be qualified for fish farming (Effendi, 2003). 


\subsection{The Results of Growth and Survival Rate of Milkfish Farming}

The variable changing which was observed in this study was the growth and survival rate of milkfish during the nursing period for four months. The fish farming was conducted in the abandoned land of former red stone excavation. The results of observation and analysis for these two variables changing, which were observed, were presented as follows:

\subsubsection{The Growth Rate}

To determine the growth rate of milkfish during the eight months of nursing process, the sampling was taken for eight times, i.e., once in a week. The total sampling was $5 \%$ to $10 \%$ from the total of testing organisms' population. The growth rate of milkfish during four months of nursing process based on the sample revealed that (2) 15 grams, (4) 30 grams, (6) 44 grams, (8) 58 grams, (10) 77 grams, (12) 88 grams, (14) 108 grams, and (16) 121 grams. The results analysis of the milkfish growth for 16 weeks gained that an average value was 117 grams; therefore, the daily growth rate was 0.73 gram.

The analysis results of the milkfish growth for 160 days of nursing on the pool of former red stone excavation were categorized in slow level if it was conducting in the pond. This was assumed that one reason that the former red stone excavation was fresh water, while the pond water contained brackish salinity; even the milkfish was categorized eurihalin fish, i.e., the organisms species that have the ability to adapt to the salinity different levels (Murtidjo, 2002). Furthermore, Nurdjana (1989) states that every living creature in balancing osmoregulation requires energy, hence, all the aquatic organisms that inhabited in the different salinity levels with liquid in their body will get the growth retardation, because of the energy obtained from food are mostly used to process of osmoregulation, which should be used for growth.

\subsubsection{The Survival Rate}

The analysis results of the milkfish survival rate in the fish farming business by using the stick net cage system in the land of former red stone excavation reached $86 \%$. The analysis showed that the milkfish species was one of the fish species of brackish water which had very high adaptation level to the environment, even if the environmental conditions were less technically qualified as an ecologist. This was consistent with the research results of Hamzah (2014) which states that milkfish is one kind of brackish water fish species that have ability to adapt to the conditions of the aquatic environment that is not good, if it compare with other aquatic organisms such as tiger shrimp.

One of the characteristics of an excavated red stone's water was closed-characteristic that the water circulation was relatively small, generally it was only contributed by constantly addition either from rainwater, irrigation or other water sources. This happened because the water of excavated red stone were originally not designed as fish farming place, either for pool or pond with one of its technical water management systems, both of income and expenditure can be conducted by gravity. In fact, the waters of the former red stone excavation land generally had lower or deeper base pond rather than the basic channel so it is difficult to drain by gravity.

Besides clearing weeds, the land should be conducted the reclamation that included: dying pond, basic soil tillage, liming, pest control and fertilizing. These preparatory activities served to break the pest cycles, improve soil structure, neutralize toxic substances and the $\mathrm{pH}$ of soil and improve soil fertility. The fertilizing process either organic or inorganic fertilizer should be careful, does not to give overdose, therefore, causing nutrient enrichment and leads to eutrophication, keep in mind that the waters of the former land of red stone excavation are generally closed-characteristic of waters so that they are potentially blooming because the water circulation is relatively small.

\section{Conclusion}

\subsection{Conclusions}

The results of the study related to milkfish farming by using the stick net cage on the land former of red stone excavation which was as abandoned land revealed that (1) the measurement and analysis of water quality during the study showed in decent condition and qualify as milkfish farming media, except salinity, (2) the results analysis of the absolute growth rate of fish for 160 days were obtained for 117 grams with a daily growth rate of 0.73 gram per day, and (3) the survival rate was $86 \%$. Both variables were observed for relatively slow growth rate, and for the high survival rate with the ecology of the land of former red stone excavation.

\subsection{Suggestions}

Based on the conclusions in this study related to the fish farming activity on the land former of red stone excavation, it can be advised that to improve the productivity, such as: (1) one of the failure factors of fish 
farming in the land former of red stone excavation is the existence of some weeds, i.e., wild grasses which are grown in cage, therefore, before the land is used as the fish farming cage, the land should be cleaned from weeds so that the land is free the pests, (2) the land processing, calcification, pest eradication and fertilizing should be conducted for the pool, and (3) besides the land use of stagnant water for fish farming, it should be also improved the integrated farming systems, such as longyam and aquaponik, hence, the land is more productive.

\section{References}

Ciptanto, S. (2015). Top 10 Ikan Air Tawar .Panduan Lengkap Pembesaran Secara Organik di Kolam Air, Kolam Terpal, Keramba, dan Jala Apung. Lily Publisher.

Dahuri, R., Rais, J. Ginting, S. P., dan Sitepu, M. J. (1996). Pengelolaan Sumberdaya Wilayah Pesisir dan Lautan Secara Terpadu. Jakarta: P.T. Pradnya Paramita.

Effendi, H. (2003). Telaah Kualitas Air, Bagi Pengelolaan Sumberdaya dan Lingkungan Perairan. Yogyakarta: Kanisus Publisher.

Gentungan's, B. P. D. (2014). Buku Potensi Desa Gentungan Kecamatan Bajeng Barat, Kabupaten Gowa, 2014 Propensi Sulawesi Selatan.

Gowa's, B. P. S. (2013). Badan Pusat Statistik, Kabupaten Gowa Dalam Angka 2014 Propensi Sulawesi Selatan.

Hamzah, M. S. (2014). Efektifitas Alat Pemeliharaan terhadap Sintasan dan Pertumbuhan Anakakan Karang Mutiara di Teluk Kodek, Lombok Utara. Journal of Ilmu Dan Teknologi Kelautan Tropis, 6(2).

Murtidjo, B. A. (2002). Budidaya Ikan Bandeng. Yogyakarta: Kanisus Publisher.

Nurdjana (1989). Petunjuk Budidaya Udang dan Ikan Bandeng di Tambak. Brackish Water Aquaculture Center of Jepara. The Ministry of Agriculture of Republic of Indonesia.

Poernomo, A. (1992). Pemilihan Lokasi Tambak Udang Berwawasan Lingkungan. Jakarta: Fisheries Research and Development Agency for Agricultural Research and Development.

Sudirman, S. P., \& Iwan, A. (2003). Mina- Padi. Budidaya Ikan Bersama Padi. Jakarta: Penebar Swadaya.

Suyanto, S. R. (2002). Budidaya Ikan Bandeng. Jakarta: Penebar Swadaya.

\section{Copyrights}

Copyright for this article is retained by the author(s), with first publication rights granted to the journal.

This is an open-access article distributed under the terms and conditions of the Creative Commons Attribution license (http://creativecommons.org/licenses/by/4.0/). 